\title{
THE LAWYER'S ROLE IN LAND-USE PLANNING
}

\author{
J. B. MILNER*
}

The lawyer's role in land-use planning is not, of course, very different from his role generally, but there may be an important difference of emphasis. The role is here considered in the First Part, in advocacy; in the Second Part, in policy formulation; and in the Third Part, in drafting. These three classes of activity are by no means mutually exclusive but they may serve as a simple framework within which to observe the lawyer's activities, despite the inevitable mix.

\section{OPPORTUNITIES FOR ADVOCACY}

\section{Judicial Appeals}

Law students, who suffer from over-exposure to cases in their classes, sometimes get the impression that a lawyer's life is one continuous law suit. A quick glance at the reports will reveal that the lawyer's role in litigation in Alberta courts is not very demanding in terms of quantity. And half a dozen planning cases over the nearly two decades of recent planning would hardly keep the wolf from the office door. ${ }^{1}$ But litigation is important in two ways. Not only does a lawyer have an opportunity to influence the court on behalf of his client, but the results of litigation in which he does not participate are also important to him because they enable him to predict what courts might do in foreseeable circumstances. It is the lawyer's special responsibility to be able to anticipate disputes that might be litigated and help his client, be it a private individual or some public authority, to provide against the contingency. For this responsibility the lawyer must have gained as much vicarious experience from reading reported relevant litigation as he can, and since his role in land-use planning is concerned primarily with statutes, he must, of course, be thoroughly familiar with the attitude courts may be expected to take to the interpretation of those statutes. ${ }^{2}$

\section{Administrative Appeals}

The lawyer's role as an advocate in administrative appeals is far more important, quantitatively at least, in land use planning. While he will rarely appear in court, his opportunities for assisting his client before various administrative agencies, ${ }^{3}$ especially in Alberta, are manifold. In this part the opportunities are identified; in the next part something will be said of the peculiar task confronting the lawyer trying to take advantage of the opportunities.

- LL.B. (Dalhousie), LL.M. (Harvard), Professor, Faculty of Law, University of Toronto.

1 A quick glance actually revealed a full dozen of cases decided on the principal planning legislation since 1948, which could be taken to be the real beginning of the current legislation. Of these twelve cases over half were decided in the 1960's. The curve is obviously rising!

2 Modernly trained law students presumably are well versed in interpretation, but they may still read, with profit, Willis, Statutory Interpertation in a Nutshell (1938), 16 Can. Bar Rev. 1 .

3 The opportunities under Ontario law are set out in Milner. "Administrative Appeals Under Planning Legislation" in Municipal Law, Special Lectures of the Law Society of Upper Canada, 1956, at 117-148. 
In his role as advocate the lawyer will appear before a wide variety of law-making and law-applying bodies. Collectively, these bodies may prepare and adopt a preliminary regional plan, ${ }^{4}$ a regional plan, ${ }^{5}$ a general plan, ${ }^{6}$ exercise development control, ${ }^{7}$ adopt a development scheme, ${ }^{8}$ pass zoning by-laws and hear appeals in respect of them, ${ }^{\circ}$ control subdivision $^{10}$ and prepare replotting schemes. ${ }^{11}$ Normally these functions are optional-planning in Canada is rarely mandatory ${ }^{12}$-but in Alberta, when the Minister of Municipal Affairs is satisfied that it is in the public interest that a municipal council should prepare and adopt a general plan he may order the council to do so within a specified time, and on default by the Council the Minister may himself plan for the municipality. ${ }^{13}$

\section{In Regional Planning}

The preliminary regional plan and the regional plan are to be prepared by a regional planning commission established by the LieutenantGovernor-in-Council pursuant to section 9 of the Act. The preliminary regional plan is intended to govern development control until the regional plan is adopted. No statutory hearing is prescribed in connection with the adoption of the preliminary plan, but each public authority having jurisdiction within the region may make representations with respect to the plan and the commission must consider them before adopting the plan. ${ }^{14}$ Hence the lawyers for these authorities can assist in the preparation of the representations.

A proposed regional plan may be provisionally adopted, but before it is confirmed the commission must hold a public hearing ${ }^{15}$ at which "representations by property owners and other interested persons" must be heard. ${ }^{16}$

Both the preliminary and the final regional plan only come into effect upon being approved by the Provincial Planning Board ${ }^{17}$ and one might have thought that any interested person could obtain a hearing at this stage, but the specific provision for appeals to the Board by a council $^{18}$ or the commission ${ }^{19}$ may suggest that no private person could appeal. This view is further encouraged by the fact that a public authority has the same right of appeal as the council. ${ }^{20}$ The Board must

\footnotetext{
4 The Planning Act, 1963 S.A., c. 43, ss. 71-73. The Planning Act is hereinafter cited as the Act.

5 Id., ss. 74-76.

6 Id., s. 95

7 Id., ss. 100-113

8 Id., ss. 114-118.

I Id., s. 119.

10 Id., Part 2, ss. 16-26. See also The Subdivision and Transfer Regulation, Alberta Regulation $361 / 63$, as amended by Alberta Regulation $433 / 63$.

11 Id., s. 28.

12 See, for a rare example. The Metropolitan Winnipeg Act, 1960 S.M., c. 40, s. 79 (i): ". . the metropolitan council shall ... as soon as it is practicable, cause to be prepared ... a plan."

13 Act, s. 142 . Similar powers may be exercised in respect of development schemes, development control, and zoning, ibid.

14 Id., s. 74. "Public authorities" include a Minister of the Crown and any council, school board, hospital board or other public body with powers to use or develop land for public or community purposes, s. (o).

15 Id., s. 76.

16 Id., s. 75.

17 Id., s. 78.

18 Id., s. 85.

19 Id., 8. 86

20 Id., s. 80 (3)
} 
hold a hearing but it need give notice in writing only to public authorities that it thinks are concerned.21

Amendments to either the preliminary or the final regional plan must follow the same procedures with respect to hearings as were followed in the original adoption or confirmation. ${ }^{22}$

\section{In Municipal Planning}

Subsidiary only to the regional plan, the general plan lies at the heart of the planning process. No hearing is required in connection with the preparation ${ }^{23}$ of this potentially important document, but presumably a lawyer has reasonably good access to the staff for purposes of discussion of his clients' problems. The private meetings with staff may be much more productive of understanding than the public appearances before council, but the staff can, at best, recommend proposals -the council has the final choice. The council's final choice is expressed by by-law, and there are elaborate provisions for the required hearing during the passing of the by-law, 24 which only comes into effect when it is approved by the Provincial Planning Board. There is no express provision for a hearing then. ${ }^{25}$ The general plan must conform to the regional plan, if any, or "any regional plan that is being prepared"26 and a council or commission may, in an appeal to the Provincial Planning Board, ask it to determine whether the general plan does indeed conform to the preliminary regional plan or the regional plan. ${ }^{27}$ Since only a council or a commission may appeal to the Board, presumably a citizen, in the course of litigation in which the issue arose, could ask a court to determine the same question of law, if such a determination is a question of law and a court is capable of handling it.

\section{In Development Control}

When development is controlled by a system of permits, each application is, presumably, a possible occasion for a discussion with some staff official, but unless the development control by-law otherwise provides the council will ultimately have to hear the applicant. A development permit is a judicial, not a ministerial order, and subject to certiorari. ${ }^{28}$ Certainly, then, the council must hear the applicant, whether it hears anyone else, although no express provision is made in the Act. But the by-law may provide for the appointment of a development control officer and the council may then, by resolution, delegate the consideration and decision of applications to either the development control

\footnotetext{
21 Id., s. 88. To date these provisions have not yet been used. (Letter from Provincial Planning Director, dated February 20, 1967, hereinafter cited as Director's letter) 22 Id., s. 84.

23 Id., s. $96(a)$ and (b).

24 Id., ss. 97 (1), 129 and 130, esp. subs. (5). So far 26 plans have been adopted in full. 3 in part, 10 more have been prepared but not adopted, and 10 more are under preparation (Director's letter).

25 Id., ss. 129, 132 and 133 . Section 6 (2) of the Act requires the Board to "hear, decide and issue orders respecting appeals in all cases where, under this Act... the Board is required to do so." (Italics added.) Unless the Act requires the Board to hold a is required to do so." (Italics added.) Unless the Act requires the Board to hold a
hearing, no hearing is necessary unless a court thinks it is necessary as an incident hearing, no hearing is necessary unless a court thinks it is necessary as an incident
of "natural justice". The Board in practice holds a hearing whenever it thinks a useful purpose will be served (Director's letter).

28 According to Kirby, J., in Re a Development Permit by Edmonton (City) (1962), 38 W.W.R. 267, at 275 .
} 
officer or the commission. ${ }^{29}$ The lawyer may thus make his representations to one of three bodies.

One would expect development control to be exercised in accordance with some kind of plan, but of course once a plan is adopted, development control is on the way out. ${ }^{30}$ Instead, the control is exercised "on the basis of the merits of each individual application" but "having regard to the proposed development conforming with the general plan being prepared"." Perhaps because the Legislature was afraid this reference to policy might not be very helpful, the Act goes on to authorize the council by resolution to make rules respecting the use of land and special aspects of specific kinds of development ${ }^{82}$ and a land use guide and a schedule of permitted land uses $^{33}$ to guide the development control officer or the commission, or, indeed, the council or any other body having jurisdiction. The rules, the guide and the schedule all require approval to the Provincial Planning Board, ${ }^{34}$ but there is no express requirement of a hearing before that body.

When the owner, or prospective owner, wants to develop land for a purpose on which the guide is silent, he may appeal to the council for provisional approval of the desired use. ${ }^{35}$ Again, no hearing is expressly required, but the obligation is there by necessary implication.

There may be a development appeal board" to which "a person affected" by a development control decision by the officer or the commission, may appeal and is entitled to a hearing. ${ }^{37}$ A further appeal lies from the board to the council by "a person claiming to be affected" by a decision of the board and the council shall hold a hearing. ${ }^{3 s}$ Presumably in a review on certiorari the status of a person claiming to be affected would be easier to establish than the status of a person in fact affected. Where there is no development appeal board the appeal may be taken directly to the council. ${ }^{39}$

A further appeal, from the council to the Provincial Planning Board, is provided for a "person claiming to be affected" by a decision. ${ }^{40}$ There is no express requirement of a hearing.

Finally, on a question of jurisdiction or law an appeal lies to the Supreme Court of Alberta, 41 in which appeal the lawyer for the ap-

29 The Act, s. 105. Query, whether the council can delegate to a commission if it has not provided for the appointment of a development control officer!

30 Once a plan is adopted by the councll it "shall proceed" with enactment of a zoning by-law (8. 99 (a) and once the by-law is passed, development control ceases (ss. 100 (1) (b) and 110 (2) ). In the words of the predecessor Town and Rural Planning Act, R.S.A. 1955, c. 337, ss. 68-72, development control is "interim", but see the 1967 amendments to the Act

31 The Act, s. 100 (2) (Italics added).

32 Id., s. 106 (1).

33 Id., s. 107 (1).

34 Id., s. 106 (2):

3s Id., s. 107 (2):

36 Id., s. 109. Members, not fewer than three, are annually appointed by the councll, at least one of them must be a member of the council, the majority must not be, nor may "officials or servants" of the council, or members of the planning commission be appointed.

37 Id., s. 110 (1) as amended, 1965 S.A. c. 70, s. 23. The appeal must be taken within ten days after receipt of the decision. S. 110 (2) requires the board to "hold a hearing of each appeal" and s. 145 provides that the Provincial Planning Board shall prescribe rules of procedure and the board must allow every person concerned to "hear the evidence of others."

38 Id., s. $110(3)$ (Italics added) as amended 1964 S.A., c. 68, s. 11. Time for appeal is imited to ten days.

39 Id., s. 146 (1) (b).

40 Id., s. 110 , ss. (5) $-(8)$, as added by 1965 S.A., c. 70, s. 23. Appeals are heard resularly (Director's letter).

41 Id., $8.146(1)$. 
pellant citizen may have to answer to argument made on behalf of the council itself. ${ }^{42}$

\section{In Development Schemes}

A development scheme is a device for ensuring that a proposal in a general plan, or to be included in a general plan, will be carried out, perhaps in a particular manner, and as amplified in the scheme. ${ }^{43}$ The development scheme is an important device because, among other reasons, it may prescribe land use for a very specific and limited area,4 and it may entitle the council to expropriate land."s As in the case of the general plan, no hearing is required during the preparation of the scheme, but when it is finally adopted by by-law ${ }^{45 a}$ the same procedures apply. These procedures are outlined briefly below as they apply to a zoning by-law.

\section{In Zoning}

Except that development control is far more attractive to most councils, and just as vital to landowners as zoning by-laws, such by-laws would take first place of importance to the landowner, and hence to his lawyer. In effect, the zoning by-law, unlike development control, which is ad hoc, is of general application. In practice, however, zoning by-laws may be amended in their application to rather small and specific properties. $^{40}$ Moreover, the Act authorizes the council, in its discretion, to determine the manner in which any provision of the by-law shall apply in specific cases. ${ }^{4 i}$ That means, in short, that the by-law may permit a particular use in a zone but permit it only if the council approves the specific case. In rather odd language the Act requires to be set out in the by-law, "any particular circumstances of proposed land use" in which the council has the power. Presumably, here again, although the Act is silent, a hearing must be afforded by the council when dealing with an application for approval.

In the enactment of a zoning by-law, in the first instance and in the event of an amendment, the council must hold a hearing for "any person who wishes to make representations concerning the manner in which any provision of the by-law may affect him or any owner of land whom he represents or the public at large, or any local group of residents or property owners." 48 In addition to written representations, which may be more valuable to the lawyer in the long run than oral submissions (if they are read), oral submissions may be made, but their presentation

12 Id., s. 146(3). One would not expect to have to meet argument from the body whose decision is appealed, but the express provision here is consistent with the theory that this is not an adjudicative matter and the "public interest" is being represented. See Edmonton (City) and Laychuk v. Uram (1966), 57 W.W.R. 529, at 540-41 (Kane, J. A.). 4.1 Id., s. $114(1)$.

4i Id., s. $114(2)$ (c). The scheme may also control subdivision and regulate building.

4 Id., s. $117(1)$

4 in Id., s. 116 . See ante, n. 24.

46 Such amendments, sometimes characterized as "spot zoning" may be quashed on the grounds that they are discriminatory, if they can be shown to have been passed in bad faith, not in the public interest, and enhance some private interest. The burden is on the plaintiff and in recent years the courts have been liberal on the side of the council. See Milner, "Planning and Municipal Law" in Recent Development in the Law, Special Lectures of the Law Society of Upper Canada, 1966, at 132-140.

4: The Act, s. $123(2)$ as amended, 1965 S.A., c. 70, s. 27.

4* Id., s. $130(5)$ (Italics added). Presumably the occasional references to a representative do not mean that a representative is elsewhere excluded. $\mathbf{S}$. 130 contains elaborate provisions respecting the notice and the conduct of the hearing by the council. See the amendments of 1965 S.A., c. 70, s. 29. 
may be regulated by resolution of the council ${ }^{49}$ and such regulations must be set out in the notice of the public hearing. ${ }^{\text {so }}$ A public hearing is excused when the Provincial Planning Director has certified that an amending by-law is only "for the purpose of clarifying" an existing provision. ${ }^{51}$

A zoning by-law has no force or effect unless it has been approved by the Provincial Planning Board. ${ }^{32}$ The Board, however, in considering the by-law, apparently need not hold another hearing, since nothing in the Act expressly requires it to do so. Despite the absence of a hearing the Board may order the council to amend the by-law in a way that may seriously affect the "rights" of a person claiming to be affected by the by-law. ${ }^{53}$ Natural justice may, therefore, dictate a hearing.

In any event, an appeal lies from the Board to the Supreme Court of Alberta on a question of law or jurisdiction. ${ }^{54}$

\section{Before the Development Appeal Board}

Once the by-law is passed and approved, further appeals are available. The most general need for relief is where "the strict enforcement" of the by-law would cause "a person" "special and unnecessary hardship". A second need arises where the discretionary power of the council, or, when it has been delegated, of the commission or authorized official, has been exercised in an unsatisfactory way. A third need arises when the landowner wishes to use land for a purpose similar to those named, but not actually permitted. A fourth need arises out of the plight of the non-conforming user, who may wish to expand, or rebuild after a fire, or change to some other use. The Act takes care of these needs by permitting an appeal to the development appeal board, which must be established when the (first?) zoning by-law is passed. ${ }^{\text {ss }}$ The development appeal board must hold a hearing and notice is to be given to all persons entitled to notice by the by-law and to any others whom the board thinks should have notice. ${ }^{36}$ There is an appeal on a question of law or jurisdiction to the Supreme Court. ${ }^{37}$

\section{In Subdivision Control}

Control over subdivision of land involves a number of opportunities to be heard. Approval is required by the appropriate commission when the land lies within the city of Edmonton or Calgary, from a regional planning commission when that commission has been authorized by the Provincial Planning Board, and by the Director of the Board in other cases. $^{58}$ No formal hearing is provided by the Act, but informal staff discussions would be hard to avoid. If approval is refused, or made sub-

\footnotetext{
49 Id., s. 130 (3) (b)

so Id., s. 130 (4).

i Id., s. 134 (3).

12 Id., s. 132.

53 According to the Supreme Court of Canada, a landowner's rights are inchoate pending exercise of the zoning power, Canadian Petrofina Ltd. v. Martin and St. Lambert (1959), 18 D.L.R. (2d) 761. But $s$. 3 of the Act. which proscribes "infringing on the rights of individuals except to the extent that is necessary for the greater public interest". may suggest that a different view is permissible under the Alberta Act.

may suggest that a differ

s5 Id., s. 127 .

5a Id., s. 128 (2). See also s. 145. The Provincial Planning Board may prescribe rules of procedure and "every person concerned" must be heard and be allowed to hear the evidence of others.

st Id., s. 146 (1) (c)). See Edmonton (City) and Laychuk v. Uram, ante, n. 42, for a . discussion of the "law" question in determining a right of appeal.

s8 Id., S. $19(2)$
} 
ject to unacceptable conditions, the applicant may appeal to the Board ${ }^{59}$ except where the refusal is for failure of the plan to conform to any existing general, regional, or preliminary regional plan, replotting scheme, development scheme or zoning by-law affecting the land. ${ }^{60}$ Who decides that it does not conform is not clear and the question might be open for judicial determination. Refusal for failure to comply with a proposed plan may be appealed. ${ }^{61}$ The approving authority has ten weeks within which to decide and then the application is deemed to be refused and the applicant may appeal."2 Control is governed by The Subdivision and Transfer Regulation ${ }^{1: 3}$ and when the approving authority is of the opinion that compliance is "impracticable or undesirable because of circumstances peculiar to a proposed subdivision", the Board, in its discretion, may order the applicant relieved. ${ }^{6 *}$ There is no statutory requirement of a hearing should the Board not think the compliance impracticable or undesirable. Local approval of a plan is subject to supervision by the Director of the Provincial Planning Board, who may check the plan against the approval application. If he finds absence of conformity, or if he thinks, from independent investigation, that the plan should be reconsidered, he reports to the Board, who must hear the applicant before disposing of the plan. ${ }^{65}$

\section{In Replotting Schemes}

Replotting schemes are authorized by local councils and the usual political "hearing" is available. The Lieutenant-Governor-in-Council, on the advice of the Board, may regulate the "manner in which the consent or dissent of persons affected by a replotting scheme is to be evidenced." Other than this no hearing is prescribed except the hearing of applications for compensation by dissenters. The compensation is fixed by the Public Utilities Board."it

When a parcel of land is to be compulsorily subdivided under section 53 the owner of the land becomes an applicant and can, of course, bring himself within the provisions already discussed, but if the owner does not want to subdivide, and the council applies on his behalf, without his consent, he has no status to appeal." hearing in connection with zoning caveats issued by the Director of the Provincial Planning Board. ${ }^{\circ}$

\section{POLICY FORMULATION}

The account thus far has been confined mainly to searching out the many opportunities that the lawyer has to intervene on behalf of his client in a hearing, by making political representation, or in discussion, where he may be expected to function as advocate. The matters of substance that the advocate may raise cannot be so mechanically related.

sil Id., s. 20 (1)

in Ibid., and s. 16 (b), as amended by 1965 S.A., c. 70. s. 3.

(i) Ibid., and s. 16 (bi), as introduced by 1965 S.A., c. 70. s. 3.

1:2 Id., s. 20 (3). The application must have been in a complete and final form for ten weeks. It is surprising how ambiguous "complete and final" may turn out to be, or how difficult it is to establish the state.

63 Alberta Regulation $361 / 63$.

it The Act, s. 21.

is Id., S. 22 (6).

in Id., s. 30 (c).

ii Id., ss. 39 and 40 .

is Id., s. 55.

30 Id., ss. 58-66. 


\section{Elaboration of Statutory Provisions}

In the traditional sense, the lawyer is expected to be a specialist in statutory interpretation ${ }^{70}$ and he must help others involved in land use planning to conduct themselves within the limits prescribed by the Act. In technical terms, he must see that no ultra vires action is taken. In the matter of interpretation he should bear in mind that as long ago as Heydon's Case, ${ }^{71}$ courts were urged to interpret statutes so as to suppress the mischief and advance the remedy, to suppress subtle inventions and evasions, and to add force and life to the cure and remedy. More recently the Alberta Legislature, in contemporary language, has said that every enactment shall be deemed remedial and shall be given such large and liberal construction and interpretation as best ensures the attainment of its objects. ${ }^{72}$ The lawyer must, therefore, acquaint himself thoroughly with the objects of the Act, which are, generally, the objects of planning.

One of the major questions of interpretation is the clarification of the powers of various agencies established by the Act. The most important of these is the Provincial Planning Board, whose predecessor, the Provincial Planning Advisory Board, was examined closely by Riley, J., in Re Glenwood Memorial Gardens Ltd.'s Appeal. ${ }^{73}$ There the applicant had been granted a development permit to establish a cemetery by the Council of the Municipal District of Strathcona, and the Board, on an appeal, had reversed the decision and denied the permit. The Board took the view that there were enough cemetery plots in the area. "To overprovide for a particular use does not have regard to basic planning principles. ... It is a well established planning principle that land, whether public or private, should not be developed or diverted from its current use in advance of actual need." It It was argued that the Board had ignored alleged principles of law governing appellate tribunals; that they should not reverse when the evidence reasonably justifies the conclusion reached below. Riley, J., rejected the analogy with a court of appeal and after referring to the governing legislation, concluded that "the board can, without following the rules of legal evidence or upon its own inquiry, upon the material there before it determine the appeal."75 He found that an "examination of the material in writing before the board was quite sufficient to warrant the conclusion reached. . . . There was a contradiction in the evidence and the board no doubt found the facts that they did upon the evidence before them, supplemented by any enquiry that it may have made, as it was entitled to do."io

The writer would, with respect, agree with Riley, J., in this conclusion, but could wish that he had not relied on a passage by Lamont, J., in Northwestern Utilities Limited v. City of Edmonton, ${ }^{77}$ where it was stated:

If, in this case, the Board had asked its secretary to inquire from the various financial institutions in Edmonton if there had been any alteration in the conditions of the money market between 1922 and 1927, and the secretary had re-

io Ante, n. 2.

71 (1584), 3 Co. Rep. $79 ; 76$ E.R. 637.

i2 The Interpretation Act, 1958 S.A., c. 32, s. 11.

73 (1961), 34 W.W.R. 159.

74 Id., at 159-160.

75 Id., at 164.

Id., at 165.

77 [1929] S.C.R. 186. 
ported that there had been a certain decrease in the returns from invested capital, would it have been necessary to call witnesses to varify the report? In my opinion it would not. Nor would it have been necessary to afford to either party an opportunity to controvert before the Board the information so obtained. Then would it have been necessary to mention in the award that the fact that such altered conditions had been established to the satisfaction of the Board by a report of its secretary? I can find nothing in the Act requiring mention to be made of the evidence or of the manner of obtaining it. ${ }^{i 8}$

Unfortunately, the case for this sensible a view of the Provincial Planning Board cannot be made so easily. Neither The Planning Act nor The Town and Rural Planning Act before it contains a section similar to the one upon which Lamont, J. clearly relied, section 21 (4) of The Public Utilities Act, the material terms of which are,

The Board may in its discretion accept and act upon evidence-by the report of any officer or engineer appointed by it or obtained in such other manner as it may decide. ${ }^{70}$

All other material provisions of The Public Utilities Act seem to have been adopted in The Planning Act, but without the italicized words in section 21 (4) the conclusion reached by Riley, J. is much less convincing. The conclusion can, I think, be justified on the ground that the kinds of problems to be solved by the Provincial Planning Board are not capable of resolution by the adjudicative process. They can only be settled if the Board has its powers interpreted in the way Riley, J. interprets them. To clutter the Board with the trappings of adjudication would be quite improper.

\section{The Focusing of General Standards}

Because the problems are not adjudicative in character, Riley, J.'s observation is more puzzling in that "Nowhere in the Act is there any power either in the Council or the Board to exercise a discretion-this is a power of decision and the appeal is an appeal from such decision." 80 Surely almost every decision of a development control officer, a planning commission, a development appeal board, a council or the Provincial Planning Board involves a high degree of "discretion". There is very little in the way of statutory standard to guide any of these bodies, and there is no clear cut lis between any combination of "parties" involved in any application. The disposition of an application for a development permit may well be a judicial function for purposes of certiorari, but it is clearly not adjudication, and it is wrong to imitate judicial proceedings too closely when the object is not to make the best of a past conflict of interest, but to formulate and apply in a particular case (in other proceedings, apply in more general cases) an effective, forward looking policy. By contrast, what a court does well is reconstruction. To use Aristotle's distinction, adjudication is more useful in dealing with corrective, rather than distributive justice.

In any event, the Act requires that control be exercised on the basis of the merits of each individual application, having regard to the pro-

78 Id., at 194-195.

70 The Public Utilities Act, 1923 S.A., c. 53. See now, The Public Utilities Board Act, 1960 S.A., c. 85, s. 32. The Planning Act does have s. 145, which requires the Development Appeal Board or the council, or both, not only to permit "every person concerned" to submit evidence, but to hear the evidence of others. Query, whether Riley, J.'s views could apply to either the Board or the council?

80 Re Glenwood Memorial Gardens Ltd.'s Appeal, ante, n. 73, at 164. 
posed development conforming with the general plan being prepared; $;^{31}$ that is, not yet fully formulated. Admittedly, when a council has made "rules" under section 106(1), the commission or development control officer "shall be governed" by them, and since the Provincial Planning Board must approve such rules, a development permit that departs from them might be thought to be an amendment of them, ${ }^{82}$ and hence, possibly, also to require the approval of the Board, although the Act does not expressly so provide. Whether a "guide" or "schedule" prepared under section $107(1)$ is binding is less certain. One can conceive of a "guide" that is not so strictly binding as a "rule".

The standards set forth in the Act, to be applied in the exercise of these many powers in respect of which hearings are required, are important for the lawyer trying to help his client. In fact the standards, because they are so generally stated, are no real guide, but they at least show in what direction to look for help.

The basis of rational land-use control is, suitably enough, planning. Regardless of what the Act says, the generally accepted demands of the planning discipline require, as a minimum, two elements. One is a study of land use, and the other is a study of the density, or intensity, of the various uses in various places. The two should result in proposals that may be stated in more or less general or specific terms. If the movement of people and goods is included in land use ${ }^{83}$ and if the element of time is at least implicit, if not explicity stated, these two elements, of land use and density, may be a satisfactory minimum. Some authorities on planning would also require, in the minimum, some consideration of financial capacity to realize municipal service proposals essential to land use development, while others think it not a part of urban planning. ${ }^{84}$

The most frequently recurring general language of the Act is to be found first in section 3 , which relates the purpose of the Act to the achievement of "orderly and economical development of land within the Province". Section 96 brings this general language a bit closer to some useful guide. Paragraph (h) makes it clear that whatever is put into the plan documents, the preparation must include "surveys and studies" of land use, population growth (a bare hint at the density question $^{85}$ ), the economic base of the municipality (financial capacity), the transportation and communication needs, public services and social services, including roads, water, sewers, schools, parks and recreation grounds. Although the element of time is not mentioned, it is clearly relevant to the studies because paragraph (c), which says what the

S1 The Act, s. 100 (2) as to development control. See also s. 110 (2) as to appeals to the Development Appeal Board or council and s. 110 (4) as to appeals from the Board to the council. See also s. 128 (3) where reference is to be had by a Development Appeal Board. on an appeal under subs. (1) to the "general purposes and intent" of the zoning by-law as well. In City of Medicine Hat et al v. Rosemount Rental Developments Ltd. (1964), 49 W.W.R. 449. Porter, J. A. (dissenting) thought the Provincial Planning Advisory Board could not legally consider an appeal without the evolving general plan before it. The majority did not share his concern.

x. Cf. Campbell et al v. City of Regina (1966), 58 D.L.R. (2d) 259.

s3 The physical basis of transportation, or circulation, i.e., streets, railways, airports and so on. Is, in a sense, a use of land.

s4 T. J. Kent, J., in his recent study, The Urban General Plan, rejects both timing and financing. or capital budgeting. from his concept of the plan. See esp. pp. 20-22 and 95. Whether or not they are included in a document called a plan, a municipality's capacity to pay and its intentions as to timing are essential to the statement of any realistic proposals.

8. Density may be prescribed as to any zone in the zoning by-law, 5.121 (1) (d) (iii) and a "general plan shall include proposals as to the content of a zoning by-law" (s 96 (c) (ii) ). 
plan document must include, specifically requires, in subparagraph (iv) "a schedule setting out the sequence in which specified areas of land may be developed or redeveloped" and services provided. And subparagraph (v) requires "proposals relating to the financing and programmnig of public development projects and capital works."8sa

Section 69 of the Act offers another indication of what is relevant in planning appeals and negotiations, but the language closely parallels that of section 96 except that it applies to regional plans and hence is of more general application.

Some further assistance may be had from a study of section 121, which sets out some of the matters that may be dealt with in zoning by-laws, the proposals for which must be set out in the general plan. ${ }^{86} \mathrm{~A}$ study of an actual by-law will be more revealing, especially if it is a sophisticated one, a flattering epithet reasonably applicable to the City of Edmonton by-law." Also revealing will be a study of Part Two of The Subdivision and Transfer Regulation, ${ }^{8 *}$ especially the regulations dealing with the suitability of the land for development, factors governing design of subdivisions, the crucial matter of services to be supplied at the cost of the subdivider, and the equally crucial matter of land to be reserved for public purposes.

These standards are vague, but they indicate the relevance in modern planning of the social sciences, especially economics, geography, politics, and sociology. A lawyer is not expected to be a master of these subjects, but he is expected to realize that his own specialty is the action side of the social sciences, with which he must have a speaking acquaintance. $\mathrm{He}$ is the problem solver who has to bring together persons of varying interests represented in planning situations and use his skill as a negotiator to help them see their interests in a new light. He must try to get for each all that the situation is capable of giving him-frequently far more than each is likely to think possible without the lawyer's help. It is, or should be, a special skill of the lawyer to analyse situations in such a way that he can help one man see his own problems in the light of another man's problems and bring them to realize the greater extent of their common interests. He does this frequently in the business world of contracts. He is less familiar, perhaps, with the socio-economic world of planning, but his talents are surprisingly adaptable.

The conservative lawyer is likely to feel rather ill at ease when he is confronted with vague standards in a statute. Yet the subject matter hardly permits of any more specific statement at that stage, and when laws have to be so generally stated, the procedures for working out their precise application become of first importance, hence the emphasis; in

\footnotetext{
85a Italics added.

86 The Act, s. 96 (c) (1i). The amendment of s. 121 in 1965 S.A., c. 70, s. 25, by the addition of the words "amongst other matters", makes s. 121 less of a restrictive code and more of an illustrative list. Zoning by-laws are discussed generally in Milner. "An Introduction to Zoning Enabling Legislation" (1962), 40 Can Bar Rev. 1, esp. at "An Introduction to Zoning Enabling Legislation" (1962), 40 Can Bar Rev. 1, esp. at Royal Architectural Institute of Canada (1964).

37 The Zoning Study Committee, ante, n. 86, found the Proposed Comprehensive Amendment to the Lake Country Zoning Ordinance of 1939 as amended (1962), published by the Lake County Regional Planning Commission, Illinois, U.S.A.. the most interesting example of recent zoning policies and techniques.

88 Ante, n. 10 . See esp. regulations $13,14,16,23-31,18$, and 19-21.
} 
the first Part, on hearings, where these vague standards can be discussed and focused more sharply. To some extent, at this point, a client's interests can be better understood and explained, and protected. The role of the lawyer is seen then, in an institutional sense, to be that of contributor to the focusing of general policy. He would be foolish to fancy himself a planner, but he would be doing a grave disservice to his client if he did not explore questions of substance with him, and with expert consultants to make sure that his client can put his best foot forward in dealing with the various agencies involved.

\section{The Ethics of Advocacy in a Legislative Forum}

Justice Brandeis, who was a generation ahead of his time in administrative law practice (and two generations ahead of most Canadian lawyers), appeared to doubt whether a lawyer was entitled to help his client put his best foot forward. Justice said,

Some men of high professional standing have even endeavoured to justify their course in advocating professionally legislation which in their character as citizens they would have voted against. ${ }^{\text {(s) }}$

He criticized this position with the assertion that

the counsel selected to represent important private interests possesses usually ability of a high order, while the public is often inadequately represented or wholly unrepresented.90

One has to admit that Justice Brandeis' libel of municipal lawyers, especially those in full time municipal practice, may be secure in the defence of truth, at least in part, but that merely makes a strong case for paying higher salaries for city solicitors, not for limiting argument by private solicitors.

While a lawyer should not be prevented by his ethics from putting his client's case with all the force at his command, he should be very careful to maintain his identity as an advocate. It is when a lawyer is tempted to put his client's case as if it were his own that he does the thing Justice Brandeis was legitimately concerned about. This same ambivalence has caused trouble for a professional planner who is sometimes asked, in his capacity as a "witness", under oath, whether he thinks a certain planning proposal is a "good" one. If he is an employee of a planning commission or a council, he may answer that his employers have chosen to accept the proposal. That is, presumably, a fact that he can testify to, while under oath. If, however, he happens to think that his employers have proceeded in the wrong direction, perhaps rejecting his advice along the way, he may be tempted to answer by "testifying" about his own views. He may, as a result, antagonize his employers, who naturally want their view to prevail, and he will, in any event, go beyond his proper role as a witness and for the moment put himself in the place of an advocate, or the tribunal itself, which has to decide whether the proposal is "good"-that is, whether it ought to be adopted, or approved.

There are many matters about which a planner can testify as an expert. It should be apparent from the question whether his answer will

89 Louis D. Brandeis, in The Opportunity in the Law, in Business-a Profession (1925),

30 Id., at 340 . 
be "fact" or "advocacy". He can, for instance, if he is a specialist in urban design, say how long a shadow a highrise building will cast at different seasons of the year and at different times of day. He might even have textbook knowledge of the effect on physical health of living in a constant shadow. But he has no special "facts" or "expert opinion about facts", that enable him to testify that it is "good" or "bad" to live in a constant shadow. Whether people should or should not so live, is not so much a "fact" as a complicated choice involving several conflicting considerations that are usually unmeasurable and can only be resolved by the exercise of judgment-"value judgment", as it is popular to say these days.

Neither the planner nor the lawyer has any business presenting his own personal views to a tribunal unless he is clearly understood to be speaking for himself and not as an advocate. He should then only be heard if he is amongst those whom the proceedings were designed by law to hear. Admittedly, in most planning appeals the tribunal is looking for help wherever it can be obtained, but even then it should not be obtained through advocacy under oath. Nor should a lawyer be able to "cross-examine" his opponent in such circumstances.

When a lawyer has nothing of substance to say on behalf of his client, he is sometimes tempted to exploit the statutory procedures by making the most of every opportunity they offer for delay. The review of procedures in the first Part discloses many such opportunities, and lawyers may feel that time is on their side. If something can be challenged, and a decision can be delayed a week, or a month, something, as Micawber was to say, is bound to turn up. But if a lawyer's sole function is to get the most he can for his client by any strategy, including delay tactics, then he should hardly complain if he finds that delays are sought by the other side as well. Nor should he complain if his client decides to drop his development altogether.

The answer to exploitation of procedures by lawyers may be to streamline the procedures, but they cannot be so streamlined that they endanger the public interest they were designed to protect. As long as we depend upon private development for the bulk of all community development, we must seek a compromise in procedures that enables public officials to ascertain and protect the public interests without sacrificing the private development the success of which is itself a public concern.

All development is dynamic, and changes its character from time to time, and public intervention is, for that reason, necessary from time to time. Careful study might, however, indicate some simpler procedures that are acceptable.

\section{DRAFTING}

It is possible to take quite a different view of the role of the lawyer in the institutional procedures so far considered. To this point the lawyer has appeared as an advocate attempting to influence on behalf of his client, public or private, the focusing of planning policy. He may also contribute to the formulation of policy while engaged in another traditional role, that of draftsman. His skills in that field are commonly accepted in private areas, such as contracts, wills, the incorporation of 
companies, and even in public areas, such as the drafting of provincial statutes and, probably to a lesser extent, in the drafting of administrative regulations. Somehow or other the value of his services has not been so apparent in planning circles, where zoning by-laws are frequently drafted by laymen and the lawyer's skills seem to have been overlooked. Yet it is one of the lawyer's major talents to know how to do things with words. ${ }^{91}$ Especially he should know how to draft language that will guide people's future action. Another talent is to anticipate trouble and advise how to avoid it with carefully worked out arrangements.

We may explore the lawyer's role in drafting by considering the drafting of a document that is usually prepared by laymen. Indeed, many lawyers would throw up their hands if asked to contribute to it. The document is the general plan.

A lawyer should not be put off by section 96 (a) of the Act, which prescribes that a general plan shall be prepared under the direction of officers or consultants qualified in planning. The meaning of "qualified" in this context is nowhere defined in the Act, although The Subdivision and Transfer Regulation does define "planner" in Clause 2 (21) as meaning a person who is a member of a recognized town planning institute, or "who holds a recognized formal professional planning qualification". Not only should the lawyer not be put off by this requirement, but more importantly, he should not rely on it as an excuse for not contributing. If he is a municipal solicitor he should regard it as his professional duty to seek out the qualified planning officer or consultant and insist upon his collaboration in the production of the plan.

Planners are fond of calling the general plan a "legal document". For some of them, at least, this is a term of opprobrium. It may account for their distaste for plans and their notorious reluctance to produce them to the point of official approval. In a very real sense, of course, the general plan is a legal document. When it has been adopted by by-law and approved by the Provincial Planning Board, no public authority, including the council, "shall. ... enact any by-law, take any action or carry out or commence any undertaking or public project that is inconsistent or at variance with it".92 The plan is, therefore, something of a partial constitution for the various branches of the local government. It is important that the language in which it is written be composed with the greatest of care. It is all the more surprising that in this country one rarely hears of the fruitful collaboration between planner and lawyer that the problem requires.

Some lawyers may regard the task of drafting as one that comes at the end, when the policies have been settled. This is far from the case. Very little experience in drafting is required to discover that the restatement of policy in legally effective language forces a reconsideration of the policy at frequent intervals. In settling the policies regard must

01 Jacques Barzun, in his House of Intellect, pays a handsome tribute to the legal profession: "The law is a model of intellectual work, and it is a work of words ..... [A]s an attempt of the esprit de finesse to mold coherent conceptions of the true and the just on the restless multiplicity of human life, it is a triumph of articulateness and exactitude." (At 247-48). Lawyers will rerognize a tacit tribute to their use of words in John L. Austin's How To Do Things With Words, a philosopher's look at a use of words long taken for granted by lawyers.

92 The Act, s. 99 (b). In Fransden v. Lethbridge (City) (1965), 52 W.W.R. 620, 622, Riley, J. suggests that the plan does not affect the publlc. It does however, have a substantial influence indirectly. 
be had to the effect of those policies and the lawyer is the only specialist to whom the planners can turn for assistance in respect of legal effects. In fact, it is not impossible that the lawyer may ultimately advise the council that it cannot get the best planning results if it retains the statuory legal effect. The statute itself may need amendment. In reform of the law the lawyer's role hardly needs explanation.

Since both development control and zoning by-laws must be based on the plan or the "plan being prepared" the language of the plan must be conceived of as a guide, or direction, to officials or councils, to govern their judgment. Only a lawyer is likely to appreciate the great difficulty in selecting the appropriate degree of generality that is certain enough to be some use as a guide and yet not so certain as to need frequent amendment. While "legislative history" is not normally looked at in our courts in the interpretation of statutes ${ }^{94}$ it is clear that the general plan will be scrutinized very carefully in an attack on a zoning by-law, and the court will probably look at the plan with less than the planner's sympathetic, if not sophisticated, eyes. The general plan, then, must be drafted in language appropriate for a court and a council-in this context, a destroyer and a creator.

The plan binds more than the council. It binds "any other public authority" and this phrase includes a school board, hospital board and a Minister of the Crown. ${ }^{95}$ The plan may, therefore, have to be written as a future guide to the council that adopts it and can readily initiate its amendment, and as an order to the school board or Minister. It is open to a school board or a Minister to make representations to the council before its adoption, and the Minister may have some influence on the Provincial Planning Board. Once these representations have been taken into account, the ultimate general plan is binding until amended. There is a sanction. The council may enforce the plan in the Supreme Court by restraining its contravention. ${ }^{\circ 6}$ Once again it may be dependent on a court's perhaps unfriendly reading of its text.

Since the procedure of amendment is as cumbersome as the procedure of adoption ${ }^{27}$ the draftsman may want to design his plan in such a way that some parts are less specific than others that can only be changed by formal amendment. Obviously care has to be taken that the parts that can be "changed" are not regarded by courts as unwarranted delegations of power to some lesser body to "amend". To say, for example, that the lines appearing as boundaries of allocated land uses are not to be taken as rigidly fixed in some cases, while in others the uses can be changed only by formal amendment may mean that some unauthorized person is being permitted to change the plan. ${ }^{98}$ If, however, land uses are related in principle only and not precisely located on any map, but for the sake of convenience shown in map form only in a most abstract way, the document may still give the desired control without mentioning any boundaries at all.

93 Id., as to the zoning by-law, s. 120 (1) (a) and as to development control, s. 100 (2).

94 Gosselin v. The King (1903), 33 S.C.R. 255, esp. at 264, and see Kilgour, "The Rule Against the Use of Legislation History: 'Canon of Construction or Counsel of Caution?' (1952), 30 Can. Bar Rev. 769.

05 The Act, s. 2(0).

06 Id., s. 138.

97 Id., s. $134(1)$ and (2).

os Cf. Campbell et al v. City of Regina, ante, n. 82. 
A development scheme may include a proposal for the acquisition of land, immediately or in the future, ${ }^{90}$ and to the extent that the general plan or plan in preparation anticipates such proposals the reference to the land to be acquired constitutes what the British planners call "planning blight."100 Once the state has announced its intentions to acquire a specific parcel of land it is unlikely that anyone else will be interested in acquiring it. It is virtually removed from the market. Provisions having this effect are likely to be strongly opposed and their designing and drafting should be undertaken with special attention to their effect.

The need for a lawyer's early assistance is emphasized by the role of the "plan being prepared" not only in development schemes but also in the exercise of development control. If the planning process is intended to guide private developers in their choice of land to be developed, then the drafting of any document that is made public may require the attention of the municipal solicitor. He will be concerned that proposals that are to be relied on are clearly stated, and proposals that are not to be relied on are not stated as if they were. No attempt should be made to mislead the public, of course, but neither should the public he misled by accident.

Finally, the Act intends the general plan to be read by the public at large, and the council must make it available "at a reasonable cost."101 What has just been said about private developers applies equally to the general public, although they may be thought to have rather less at stake. The draftsman of the general plan has thus to speak effectively to a council, related local government agencies, civil servants, developers with very special interests in land use and the general public. Such a diverse audience may require that the plan be divided into several parts, some having a different legal effect from others, some couched in less specific language than others, and some more easily amended than others. The very task of drafting may indicate necessary changes in the policy being drafted.

That the lawyer has a role can hardly be disputed but the importance of his lines may vary with his ability to deliver them.

99 The Act., s. 114(2)

100 See, for example, the reference in the Planning Advisory Group's The Future of Development Plans (1965), H.M.S.O. Code No. 75-148.

101 The Act, 8. 136. 